\title{
Non-steroidal anti-inflammatory drugs - potential risks and benefits in the gastrointestinal tract distal to the ligament of Treitz
}

\author{
Niesteroidowe leki przeciwzapalne - potencjalne zagrożenia i korzyści \\ dla przewodu pokarmowego dystalnie do więzadła Treitza
}

\author{
Beata Kasztelan-Szczerbińska, Maria Słomka, Krzysztof Celiński, Halina Cichoż-Lach \\ Department of Gastroenterology with Endoscopy Unit, Medical University, Lublin
}

Przegląd Gastroenterologiczny 2010; 5 (3): 145-150

DOI: $10.5114 / p g .2010 .14139$

Key words: non-steroidal anti-inflammatory drugs, adverse effects, intestinal damage, hepatotoxicity, cancer chemoprevention. Słowa kluczowe: niesteroidowe leki przeciwzapalne, objawy uboczne, uszkodzenia jelit, hepatotoksyczność, chemoprofilaktyka raka.

Address for correspondence: Beata Kasztelan-Szczerbińska, MD, PhD, Department of Gastroenterology with Endoscopy Unit, Medical University, ul. Jaczewskiego 8, 20-954 Lublin, phone/fax +48 8172445 35, e-mail: beata.szczerbinska@op.pl

\begin{abstract}
The toxicity of non-steroidal anti-inflammatory drugs (NSAIDs) related to the upper gastrointestinal (GI) tract is well established. However, they may cause injury distal to the duodenum as well - to the small and large intestine and/or to other organs of the digestive system. Non-steroidal anti-inflammatory drugs induce small intestinal perforation, ulcers or strictures requiring surgery and inflammation with blood and protein loss called NSAID enteropathy. These drugs can exacerbate pre-existing large bowel disease (e.g. ulcerative colitis, diverticular disease) and precipitate relapse of inactive disease or the new onset of inflammatory bowel disease (IBD) with rapid resolution of symptoms on their withdrawal. They have been implicated in the development of microscopic colitis. Non-steroidal antiinflammatory drugs-associated toxicity of the small and large bowel is increasingly recognized in clinical practice, as enteroscopic procedures become more frequently used. Liver injury is an uncommon, but potentially lethal complication. It can occur with all NSAIDs, but diclofenac and sulindac seem to be most commonly associated with the problem. These drugs may contribute to acute fatty liver of pregnancy. Hepatotoxicity is likely due to an idiosyncratic reaction resulting from an immunological response or altered metabolic pathways. The major benefits of NSAIDs relate to reports of possible prevention, delay or regression of progress towards cancer of the colon, oesophagus, stomach as well as of cancer of the breast, lung, prostate and skin. Despite their promise, NSAIDs are not yet recommended for prevention or treatment of any cancer, because the balance of hazards and benefits from the treatment must be resolved in the designated patient population.
\end{abstract}

\section{Streszczenie}

Toksyczność niesteroidowych leków przeciwzapalnych (NLPZ) w stosunku do górnego odcinka przewodu pokarmowego jest dobrze udokumentowana. Mogą one jednak powodować uszkodzenia również dystalnie do dwunastnicy - w jelicie cienkim oraz grubym i/lub w innych narządach układu trawiennego. Niesteroidowe leki przeciwzapalne wywołują perforacje, owrzodzenia i przewężenia jelita cienkiego, które wymagają leczenia operacyjnego, oraz stan zapalny $z$ utratą krwi i białka, zwany enteropatią. Mogą zaostrzyć objawy podstawowej choroby jelita grubego (np. wrzodziejącego zapalenia jelita grubego, choroby uchyłkowej), wtórnie wzmagać aktywność choroby nieaktywnej lub indukować pierwotny epizod nieswoistych zapalnych chorób jelit, z szybkim ustępowaniem objawów po odstawieniu leku. Sugeruje się ich udział w rozwoju mikroskopowego zapalenia jelita grubego. W praktyce klinicznej toksyczność NLPZ w jelicie cienkim i grubym rozpoznaje się coraz częściej ze względu na coraz powszechniejszą dostępność procedur endoskopowych. Uszkodzenie wątroby jest rzadkim, lecz potencjalnie śmiertelnym powikłaniem. Może się ono pojawić po użyciu każdego NLPZ, ale najczęściej problem ten wywołują diklofenak i sulindak. Niesteroidowe leki przeciwzapalne mogą brać udział w ostrym stłuszczeniu wątroby u kobiet w ciąży. Ich hepatotoksyczność jest prawdopodobnie reakcją idiosynkrazji w wyniku odpowiedzi immunologicznej lub zaburzeń metabolicznych. Najważniejsze korzyści z terapii NLPZ wykazały raporty o możliwej profilatyce, opóźnieniu lub regresji rozwoju raka w jelicie grubym, przełyku, żołądku, a także raka piersi, płuc, gruczołu krokowego i skóry. Mimo tych doniesień nie sformułowano dotychczas rekomendacji dla profilaktyki i leczenia NLPZ w przebiegu żadnego z tych nowotworów. Stosunek ryzyka do korzyści wynikający z takiego leczenia musi zostać oszacowany w badaniach w odpowiednich grupach chorych. 


\section{Introduction}

During the last fifty years, the worldwide growth in use of non-steroidal anti-inflammatory drugs (NSAIDs) in the treatment of pain, fever and inflammation of varying origin has shown that a major limitation to their clinical utility is their gastrointestinal (GI) toxicity. Since acetylsalicylic acid synthesis by Felix Hoffman in 1897 and its market introduction under the trademark Aspirin in the year 1899, it has attained a leading position worldwide in the prescription-free therapy of rheumatic and other musculoskeletal disorders [1]. Evidence collected from clinical studies and confirmed in the 1930s by endoscopic trials has indicated its extensive damage to the Gl tract. Development of NSAIDs - a class of related drugs with a similar mechanism of action, but a reduced spectrum of undesirable side effects - and their frequent everyday oral administration, has led to serious health problems, estimated in the US population at over 100000 hospitalizations and 17000 deaths per year [1]. As a result of research focused on reduction of the adverse effects of NSAIDs, selective COX-2 inhibitors, such as celecoxib and rofecoxib, have been developed. The clinical risk of adverse effects from NSAIDs is an important factor limiting their long-term therapy, especially in the elderly. These drugs have commonly been associated with upper Gl tract side effects including a high incidence of gastric and duodenal ulceration. There are many literature reports summarizing NSAIDs' gastroduodenal epithelial toxicity. However, recent reports have underlined that also other $\mathrm{Gl}$ consequences can contribute to the morbidity and mortality associated with these drugs [2]. It is possible that development of modified release NSAID forms (enteric coating or sustained release formulations) may increase exposure of the active drug to the mucosa distally to the duodenal bulb, and thereby increase toxicity to distal Gl regions where the effects are difficult to monitor. This article will focus on the prevalence, clinical spectrum and pathogenesis of NSAIDs' alterations located distal to the ligament of Treitz. We will also discuss their potential benefits in relation to a considerable amount of evidence of cancer chemoprevention in the colon and other organs.

\section{Non-steroidal anti-inflammatory drugs-induced small intestine injury}

Non-steroidal anti-inflammatory drugs-induced injury to the intestinal epithelium results from:

1) direct exposure after oral ingestion,

2) systemic effects after absorption,

3) recurrent exposure following entero- hepatic recirculation.

The first reports of small bowel injury following NSAIDs administration come from animal studies which have shown intestinal inflammation, bleeding and ulceration [1, 2]. Since new endoscopic procedures are becoming more frequently used, small intestine NSAID toxicity in humans is increasingly recognized in clinical practice. Two such techniques are video capsule endoscopy and double-balloon enteroscopy [3].

Matsumoto et al. [4] reported that in the cases indicated for enteroscopy, NSAID enteropathy occurred in half of patients taking NSAIDs. It includes ulcerations, diaphragm-like strictures, perforation, haemorrhage, occult anaemia that can develop over time, and inflammation with altered intestinal permeability associated with both blood and protein loss.

Several investigators have reported diaphragm-like strictures in chronic NSAID users [5]. These diaphragms are thin (2 to $4 \mathrm{~mm}$ ), concentric and septate-like mucosal alterations that narrow the intestinal lumen. Histologically they are characterized by prominent submucosal fibrosis without vascular involvement.

The study of Morris et al. [6] revealed that approximately half of patients with occult GI bleeding while on chronic NSAIDs administration had small bowel ulcerations.

Further studies showed that long-term NSAID treatment was associated with small intestinal inflammation and blood and protein loss as the result of increased intestinal permeability. This effect was also observed after rectal administration of these drugs, indicating their systemic action, not just only local irritation. As in the gastric mucosa, COX inhibition has been proposed to explain the injurious mechanism of their impact on the gut [7]. Kargman et al. [8] examined cyclo-oxygenase isoform-1 (COX-1) expression throughout the Gl tract. They found that COX-1 is expressed in the small intestine at levels even higher than in the stomach. The three most common sites of its expression are the duodenum, jejunum and ileum.

Some other reports indicate that inhibition of epithelial COX activity may not clearly explain the alteration of intestinal permeability. The pathogenesis of NSAID small bowel damage is probably a multi-stage process. Numerous factors have been proposed to take part in the pathogenesis of NSAID-induced enteropathy. Some of them are endogenous aggressors: neutrophils, inflammatory mediators - inducible nitric oxide, tumour necrosis factor- $\alpha$ (TNF- $\alpha$ ), intracellular adhesion molecules. Some are luminal aggressors: bile, microflora, hydrolytic and proteolytic enzymes.

Takeuchi et al. [9] found that the expression of inducible nitric oxide synthase (iNOS) in the small intestine following administration of NSAIDs results from COX-1 inhibition and is functionally associated with intestinal hypermotility and bacterial invasion. 
The results of Basivireddy et al. [10] and Hagiwara et al. [11] indicate that qualitative and quantitative changes in the luminal bacterial flora may contribute to NSAID enteropathy. Ileal ulcer formation did not occur in germ-free rats, so maintenance of normal microflora appears to be very important for the prevention of injury of the intestinal mucosa. An increase in the number of gram-negative bacteria and their lipopolysaccharide (LPS) in the mucosa induces activation of neutrophils and together with the action of NSAIDs causes ulcer formation.

It was also suggested that enterohepatic recirculation may play an important role in the pathogenesis of small intestinal injury. Experimental studies revealed that NSAIDs undergoing enterohepatic recirculation are particularly likely to cause small intestine damage [7].

Increased intestinal permeability, altered tight junction proteins and reduced blood flow caused by NSAID administration may allow different aggressors access to the intestinal epithelium and induce an inflammatory tissue reaction and subsequent fibrosis. Further consequences are both blood and protein loss, ulcerations and strictures.

\section{Large bowel damage}

Large bowel NSAID toxicity may have several different manifestations. These drugs have been reported to precipitate new lesions of the large intestine and/or exacerbate pre-existing disease [2]. Damage of the colonic mucosa associated with NSAID administration includes diffuse colitis with erosions, ulcerations, strictures located mainly in the proximal colon, and new onset of inflammatory bowel disease (IBD) with rapid resolution of symptoms after these drugs are withdrawn. There are some pre-existing disorders of the large bowel which are conducive to NSAID complications. The most common are diverticular disease and IBD. Diverticular disease occurs frequently, especially among elderly patients. One third of the general population develops diverticulosis by age 45 years and two thirds by age 85 years [12]. Most people who have colonic diverticulosis are asymptomatic and have an uncomplicated clinical course, but a small number of patients experience diverticular haemorrhage, which results from rupture of a vasa recta artery located in the wall of the diverticulum. Taking aspirin and other NSAIDs seems to confer an increased risk for low GI bleeding, in particular diverticular haemorrhage.

Patients with IBD frequently have arthralgias and pain, which may be alleviated with NSAIDs. Many physicians are under the impression that the use of these drugs by patients with ulcerative colitis or Crohn's disease is contraindicated. Whether it is safe for them to use NSAIDs remains controversial. Documenting a disease flare in IBD related to NSAID use is very rare [2]. If it does occur, it is likely related to the anti-COX-1 effect. Patients are allowed to use conventional NSAIDs sporadically, but if chronic use is needed, selective COX-2 inhibitors appear to be safer [13]. Until more data are available, it is prudent to warn IBD patients about the potential risks of using NSAIDs and to encourage alternative forms of palliative therapy.

It has been suggested that NSAID ingestion could cause or worsen microscopic colitis (MC) - a rare disease of unknown aetiology [14]. However, the scientific evidence is limited. Recent reports indicate that especially collagenous colitis (CC) is associated with administration of these drugs. Chande et al. [15] observed that $35 \%$ of 104 patients with MC identified were using NSAIDs. The results of the study of Fernández-Bañares et al. [16] indicate a trend for NSAIDs involvement in CC $(p=0.057)$. They conclude that consumption of NSAIDs increases the risk of MC. Some drugs might be trigger factors of colonic inflammation in predisposed hosts, and others might only worsen self-evolving MC.

\section{Non-steroidal anti-inflammatory drugs-associated toxicity of the liver}

The liver is a central metabolic organ for various drugs and foreign substances after their absorption and therefore it appears to be a main site of adverse drug reactions. Non-steroidal anti-inflammatory drugs-related hepatotoxicity can occur at any time after drug administration, but most commonly within 6-12 weeks [17]. The risk of clinically apparent liver damage is low (an estimated frequency between 1/100 000 and 1/10 000 treated patients), but it can potentially be serious and lethal (acute liver failure leading to liver transplantation or death) [18]. Several NSAIDs have been withdrawn from the market because of their hepatic adverse reactions (bromfenac, pirprofen, fenclofenac) [18]. Liver damage can occur with all NSAIDs, but appears to be more frequent with diclofenac and particularly sulindac $[17,19]$. The main risk factors for NSAID liver injury are: age over 50 years, female sex, coexisting autoimmune disorder (disseminated lupus erythematosus, rheumatoid arthritis), and concurrent use of potentially hepatotoxic drugs (e.g. rifampicin).

Drug-induced hepatotoxicity includes two mechanisms: 1) direct toxic reaction, after overdoses; and 2) idiosyncratic or hypersensitivity reaction, after therapeutic doses [19].

Acetaminophen is an example of an agent that causes a direct toxic reaction. Hepatic necrosis is related to depletion of mitochondrial glutathione stores. Acetaminophen-induced liver injury occurs as a result of: 1) an 
intentional suicidal overdose (more than 6 to $10 \mathrm{~g}$ per day) or 2) toxicity from drug recommended doses ( $<4 \mathrm{~g}$ per day) in patients with alcohol consumption, fasting or protein malnutrition.

Idiosyncratic reactions are unpredictable and often associated with increased anti-nuclear and/or antismooth muscle antibody titres, lymphadenopathy and eosinophilia in patients with specific hypersensitivity to the particular drug. Because of the availability of NSAIDs over the counter, it is important to identify especially subclinical cases of idiosyncratic reactions. Patients who develop NSAID-induced hepatotoxicity must be advised to stop these drugs permanently. Re-challenge with the drug results in repeat increase of liver enzymes and sometimes even in a liver transplantation [17]. Patients often have the same reactions after administration of different, particularly structurally similar NSAID. The analgesic drug of choice for these patients, even if they are jaundiced, remains paracetamol [19].

There are no published data suggesting hepatotoxicity of cardioprotective doses of aspirin. The molecular structure of aspirin lacks the diphenylamine ring related to NSAID toxicity, so its use in anti-platelet indications (doses 75 to $300 \mathrm{mg}$ per day) is safe. Aspirin-related hepatotoxicity is dose-dependent and occurs only after full anti-inflammatory doses [17].

Aspirin is not recommended for children under 14 years, because epidemiological studies have identified it as a contributing factor to the development of Reye's syndrome. It is characterized by microvesicular liver steatosis associated with encephalopathy (nausea, vomiting, lethargy, and coma) [19].

Baldwin reported that NSAIDs can be the unidentified factor which precipitates acute fatty liver of pregnancy, because its symptoms and microvesicular liver steatosis are similar to those observed in Reye's syndrome [20]. Avoidance of these drugs during pregnancy may lead to a decrease in the incidence of this complication.

Clinicians should be aware that in patients with liver cirrhosis NSAIDs may exhibit unusual adverse effects. For drugs with a high hepatic extraction (low bioavailability in healthy subjects), bioavailability increases and hepatic clearance decreases. Their initial dose has to be reduced, and their maintenance dose has to be adapted according to kinetic studies in cirrhotics. The clearance of NSAIDs may also be impaired in cholestatic patients. Accurate clinical monitoring of patients with liver disease treated with these drugs is very important [19].

\section{Beneficial effects of non-steroidal anti-inflammatory drugs in the GI tract}

Major benefits of NSAIDs relate to reports of possible prevention, delay or regression of progress towards several epithelial cancers [21]. Numerous chronic inflammatory disorders increase the risk of cancer in affected tissues. For example the inflammatory bowel diseases predispose to colorectal cancer; chronic infection with Helicobacter pylori induces atrophic gastritis, dysplasia, adenocarcinoma or gastric lymphoma [22]; adenocarcinoma following Barrett's oesophagus can develop in the course of chronic reflux of gastric juice and bile; and chronic cholecystitis with gall stones predisposes to cancer of the gallbladder. On the other hand, there are data from experimental studies showing over-expression of COX-2 during the progression of certain tumours. The review of Harris et al. [23] confirms a significant decline in the risk for 7-10 malignancies with increasing intake of NSAIDs (primarily aspirin or ibuprofen). The four major types were: colon (63\%), breast (39\%), lung (36\%) and prostate cancer (39\%). Significant risk reductions were also observed for oesophageal (73\%), stomach (62\%), and ovarian cancer (47\%).

There are only limited data available regarding the impact of NSAIDs on cancer of the pancreas. However, the meta-analysis of Larsson et al. [24] summarizing available evidence from epidemiological studies (from 1966 to October 2006) does not indicate that administration of aspirin or NSAIDs is associated with a risk of pancreatic cancer.

Beneficial NSAID effects on neoplasia became apparent after five or more years of use and were stronger with longer duration. These effects are particularly well documented in the colon and rectum. The observational data regarding colorectal neoplasia are quite strong. Several retrospective and prospective studies have reported a $30-50 \%$ reduction in the rates of CRC in humans with a regular intake of aspirin or NSAIDs [25, 26]. Sulindac and celecoxib have actually led to the regression of existing colorectal polyps in patients with familial adenomatous polyposis (FAP) [27]. There is growing evidence that the induction of apoptosis is one of the pathways in which NSAIDs prevent cancer. They may exert their chemopreventive effects by restoring normal apoptosis and reduce cell proliferation in the human colonic mucosa and in various experimental cancer cell lines that have lost genes required for normal function. Arachidonic acid has been reported to be a key signal for apoptosis [28]. The over-expression of arachidonic acid-utilizing enzymes, such as COX-2, within the colonic mucosa may promote carcinogenesis [29]. Therefore, with the increased understanding of the clinical effects of NSAIDs on cancer, the development of effective chemoprevention with these drugs appears to be a real possibility. Despite their promise, NSAIDs are not yet recommended for prevention or treatment of any cancer, because the balance of hazards and benefits 
from the treatment must be resolved in the designated patient population.

The latest data indicate another good point of NSAIDs. The prevalence of post-ERCP pancreatitis ranges from 1 to $2 \%$ in low-risk patients to approximately $45 \%$ in high-risk patients. During Digestive Disease Week 2008 in San Diego, California, Dr. Elmunzer of the University of Michigan, Ann Arbor and colleagues presented results of a meta-analysis that included 879 patients who underwent ERCP between 2003 and 2007. They have found that a single dose of NSAID, administered rectally just prior to endoscopic retrograde cholangiopancreatography, can reduce the risk of procedurerelated pancreatitis by $65 \%$ [30].

\section{Conclusions}

1. Non-steroidal anti-inflammatory drugs frequently exert irritant and toxic effects in the upper Gl tract, but may cause damage distal to the duodenum as well - to the small and large intestine.

2. Non-steroidal anti-inflammatory drugs contribute to drug-induced liver injury - the risk is rather low, but potentially lethal.

3. Major benefits of NSAIDs relate to reports that they may protect against the development of many types of cancer. Despite their promise, they are not yet recommended for the chemoprevention of any cancer.

\section{References}

1. Whittle BJ. Gastrointestinal effects of nonsteroidal anti-inflammatory drugs. Fundam Clin Pharmacol 2003; 17: 301-13.

2. Thiefin G, Beaugerie L. Toxic effects of nonsteroidal antiinflammatory drugs on the small bowel, colon, rectum. Joint Bone Spine 2005; 72: 286-94.

3. Swain P, Adler D, Enns R. Capsule endoscopy in obscure intestinal bleeding. Endoscopy 2005; 37: 655-9.

4. Matsumoto T, Kudo T, Esaki M, et al. Prevalence of nonsteroidal anti-inflammatory drug-induced enteropathy determined by double-balloon endoscopy: a Japanese multicenter study. Scand I Gastroenterol 2008; 43: 490-6.

5. Moffat CE, Khyan MK, Davies CG, et al. Diaphragm disease: the limitation of laparoscopy and assessment of the small bowel for strictures using a ball bearing. Scientific World J 2006; 6: 1139-43.

6. Morris AJ, Madhok R, Sturrock RD, et al. Enteroscopic diagnosis of small bowel ulceration in patients receiving nonsteroidal anti-inflammatory drugs. Lancet 1991; 337: 520.

7. Fortun PJ, Hawkey CJ. Nonsteroidal anti-inflammatory drugs and the small intestine. Curr Opin Gastroenterol 2005; 21: 169-75.

8. Kargman S, Charleson S, Cartwright M, et al. Characterization of prostaglandin G/H synthase 1 and 2 in rat, dog, monkey, and human gastrointestinal tracts. Gastroenterology 1996; 111: 445-54.
9. Takeuchi K, Yokota A, Tanaka A, Takahira Y. Factors involved in upregulation of inducible nitric oxide synthase in rat small intestine following administration of nonsteroidal anti-inflammatory drugs. Dig Dis Sci 2006; 51: 1250-9.

10. Basivireddy J, Jacob M, Ramamoorthy P, Balasubramanian KA. Alterations in the intestinal glycocalyx and bacterial flora in response to oral Indomethacin. Int J Biochem Cell Biol 2005; 37: 2321-32.

11. Hagiwara M, Kataoka K, Arimochi H, et al. Role of unbalanced growth of gram-negative bacteria in ileal ulcer formation in rats treated with a nonsteroidal anti-inflammatory drug. J Med Invest 2004; 51: 43-51.

12. Reuter BK, Davies NM, Wallace JL. Nonsteroidal anti-inflammatory drug enteropathy in rats: role of permeability, bacteria, and enterohepatic recirculation. Gastroenterology 1997; 112: 109-17.

13. El Miedany Y, Youssef S, Ahmed I, El Gaafary M. The gastrointestinal safety and effect on disease activity of etoricoxib, a selective cox-2 inhibitor in inflammatory bowel diseases. Am J Gastroenterol 2006; 101: 311-7.

14. Nyhlin N, Bohr J, Eriksson S, Tysk C. Systematic review: microscopic colitis. Aliment Pharmacol Ther 2006; 23: 1525-34.

15. Chande N, Driman DK, Reynolds RP. Collagenous colitis and lymphocytic colitis: patient characteristics and clinical presentation. Scand I Gastroenterol 2005; 40: 343-7.

16. Fernández-Bañares F, Esteve $M$, Espinós JC, et al. Drug consumption and the risk of microscopic colitis. Am J Gastroenterol 2007; 102: 324-30.

17. O'Connor N, Dargan PI, Jones AL. Hepatocellular damage from non-steroidal anti-inflammatory drugs. Q J Med 2003; 96: 787-91.

18. Rostom A, Goldkind L, Laine L. Nonsteroidal anti-inflammatory drugs and hepatic toxicity: a systemic review of randomized controlled trials in arthritis patients. Clin Gastroenterol Hepatol 2005; 3: 489-98.

19. Chang CY, Schiano TD. Review article: drug hepatotoxicity. Aliment Pharmacol Ther 2007; 25: 1135-51.

20. Baldwin GS. Do NSAIDs contribute to acute fatty liver of pregnancy? Med Hypotheses 2000; 54: 846-9.

21. Morgan G. Beneficial effects of NSAIDs in the gastrointestinal tract. Eur J Gastroenterol Hepatol 1999; 11: 393-400.

22. Thun MJ, Henley SJ, Gansler T. Inflammation and cancer: an epidemiological perspective. Novartis Found Symp 2004; 256: 6-21.

23. Harris RE, Beebe-Donk J, Doss H, Burr Doss D. Aspirin, ibuprofen, and other nonsteroidal anti-inflammatory drugs in cancer prevention: a critical review of non-selective COX-2 blockade (review). Oncol Rep 2005; 13: 559-83.

24. Larsson SC, Giovannucci E, Bergkvist L, Wolk A. Aspirin and nonsteroidal anti-inflammatory drug use and risk of pancreatic cancer: a meta-analysis. Cancer Epidemiol Biomarkers Prev 2006; 15: 2561-4.

25. Giovannucci E, Egan KM, Hunter DJ, et al. Aspirin and the risk of colorectal cancer in women. N Engl J Med 1995; 333: 609-14.

26. Smalley W, Ray WA, Daugherty J, Griffin MR. Use of nonsteroidal anti-inflammatory drugs and incidence of colorectal cancer: a population-based study. Arch Intern Med 1999; 159: 161-6. 
27. Steinbach G, Lynch PM, Phillips RK, et al. The effect of celecoxib, a cyclooxygenase-2 inhibitor, in familial adenomatous polyposis. N Engl J Med 2000; 342: 1946-52.

28. Cao Y, Pearman AT, Zimmerman GA, et al. Intracellular unesterified arachidonic acid signals apoptosis. Proc Natl Acad Sci 2000; 97: 11280-5.

29. Konturek PC, Rembiasz K, Burnat G, et al. Effects of cyclooxygenase-2 inhibition on serum and tumor gastrins and expression of apoptosis-related proteins in colorectal cancer. Dig Dis Sci 2006; 51: 779-87.

30. Elmunzer BJ, Waljee AK, Elta GH, et al. A meta-analysis of NSAIDs in the prevention of post-ERCP pancreatitis. Program and abstracts of Digestive Disease Week; May 17-22, 2008; San Diego, California. Abstract W1625. 